\title{
Evaluation of knowledge \& awareness of medical students on HIV/AIDS before and after teaching curriculum
}

\author{
Bharathi $\mathbf{M}^{1}$, B Naga Srilatha ${ }^{2}$, M Sasidhar ${ }^{3}$, A Sasikala ${ }^{4}$ \\ ${ }^{1 *}$ Dr. M. Bharathi M.D. Associate Professor, ${ }^{2}$ Dr. B. Naga Srilatha M.D. Associate Professor, ${ }^{3}$ Dr. M. Sasidhar M.D. \\ Professor, ${ }^{4}$ Dr. A.Sasikala M.D. Assistant Professor. All are affiliated with Department of Microbiology, RIMS Medical \\ College, Kadapa, Andhra Pradesh, India
}

Address for Correspondence: Dr. M. Bharathi M.D, Associate Professor, Department of Microbiology, RIMS Medical College, Kadapa, Email Id: bharathikanthi65@gmail.com

\begin{abstract}
Introduction: The HIV/AIDS pandemic has become one of the most important public health problems in recent times. India has the $3^{\text {rd }}$ highest number of estimated people living with HIV/AIDS (PLHA) in the world. It is an urgent necessity that the doctors of tomorrow are prepared to deal with the many outcomes of the spread of HIV infection in the community. WHO strongly recommends the incorporation of knowledge of HIV/AIDS in medical syllabus starting from the $1^{\text {st }}$ year. Methods: A Prospective study was conducted to assess the knowledge and awareness of medical students and effectiveness of curriculum on HIV/AIDS at RIMS Medical College, Kadapa, Andhra Pradesh in July and September 2015. 150 students of $4^{\text {th }}$ semester were included after taking their consent. A questionnaire having 30 items of closed ended except three and subjective items were administered. Base line knowledge was assessed by pretest evaluation. Post-test evaluation was done two months after teaching curriculum for two hours. Results: The knowledge of students after teaching curriculum regarding HIV/AIDS was high in all aspects when compared to pre intervention. Conclusions: Awareness of students on HIV/AIDS was improved in post-intervention assessment.

1. Few students (11/150) only knew about p 24 antigen.

2. Students' knowledge about vertical transmission and non-modes of transmission of HIV still needs intervention.

3. Regarding vulnerable groups, symptoms and testing strategies - their awareness was poor.
\end{abstract}

Key words: Curriculum, Medical Students, HIV/AIDS

\section{Introduction}

The HIV/AIDS pandemic has become one of the most important public health problems in recent times and it is having a profound impact on the lives of infected people and their families [1]. And it has full impact on developing countries in the eastern hemisphere, focusing especially on Asia. The major brunt of the HIV epidemic has been in South and South-east Asiapredominantly in India and Thailand [2]. India has the $3^{\text {rd }}$ highest number of estimated people living with HIV/AIDS (PLHA) in the world [3]. Even though antiretroviral treatment for HIV/AIDS can slow down the course of the disease, there is no known cure or vaccine. Preventing the infection is the key aim in controlling the AIDS pandemic [4].

Manuscript received: $2^{\text {nd }}$ Oct 2015

Reviewed: $9^{\text {th }}$ Oct 2015

Author Corrected: $14^{\text {th }}$ Oct 2015

Accepted for Publication: $27^{\text {th }}$ Oct 2015
Health care providers, particularly physicians, will also have to learn to protect themselves and those that come to them for medical help. However, it is an urgent necessity that the doctors of tomorrow are prepared to deal with the many outcomes of the spread of HIV infection in the community. What is needed is a conscious decision to focus and stress those aspects that are important to HIV medicine and to use examples from HIV when teaching general principles. The teaching of the different elements of the core curriculum would then permeate through the entire course, with almost every department taking an important responsibility. By involving all the teaching departments in meeting the objectives defined for the overall course in HIV medicine for undergraduate medical students, the course can be smoothly 
incorporated into the curriculum with no apparent extra burden on the student. Particularly in the case of a newer subject of learning such as HIV/AIDS, assessments can guide the teachers as well as the students about parts of the course that have been successful and parts which need to be improved [5]. With the above background we made an attempt to assess the impact of curriculum on HIV/AIDS on the knowledge of medical students.

\section{Aims \& Objectives}

1. To assess the knowledge and awareness of Medical students on HIV/AIDS before and after teaching on the curriculum of HIV

2. To assess the effectiveness of curriculum on HIV/AIDS in acquiring the knowledge of medical students.

\section{Material \& Methods}

\section{Results}

Almost all students knew about World AIDS day. The knowledge of students before teaching curriculum regarding acronym of NACO, influence of HIV on immune system, receptor \& unique enzyme for HIV was around 50\% as shown in Table $1 \& 2$. First antigen to appear in blood after infection was not known by most of them even in post intervention session. The percentage of students who answered correctly regarding Modes of Transmission of HIV/AIDS, routes by which HIV/AIDS is not transmitted was high in post intervention test as shown in Table 3 and 4 . Awareness on HIV/AIDS, as it is not transmitted by sharing of rooms, toilets \& clothes was improved in post intervention evaluation as shown in Table 4.

Table 1: Showing results on current affairs

\begin{tabular}{|l|l|l|l|l|}
\hline Item & $\begin{array}{l}\text { Pre-test Number } \\
(\%) \\
(\text { Total no-150) }\end{array}$ & $\begin{array}{l}\text { Post-test } \\
\text { Number }(\%) \\
(\text { Total no-150) }\end{array}$ & $\begin{array}{l}\text { Chi -square } \\
(\mathrm{df})\end{array}$ & $\mathrm{p}$ value \\
\hline World AIDS day & $144(96)$ & $149(99.33)$ & $3.65(1)$ & $>0.05$ \\
\hline Acronym of NACO & $72(48)$ & $145(96.66)$ & $88.76(1)$ & $<0.001$ \\
\hline Red ribbon stands for & $23(15.33)$ & $128(85.33)$ & $147(1)$ & $<0.001$ \\
\hline AIDS slogan for 2014 & - & 1 & & \\
\hline
\end{tabular}

Table 2: Showing results on knowledge about HIV

\begin{tabular}{|l|l|l|l|l|}
\hline Item & $\begin{array}{l}\text { Pre-post Number }(\%) \\
(\text { Total no-150) }\end{array}$ & $\begin{array}{l}\text { Post-test Number }(\%) \\
(\text { Total no-150) }\end{array}$ & $\begin{array}{l}\text { Chi -square } \\
(\mathrm{df})\end{array}$ & p value \\
\hline Influence on Immune system & $87(58)$ & $110(73.33)$ & $7.82(1)$ & $<0.01$ \\
\hline Receptor for HIV virus & $65(43.33)$ & $106(70.66)$ & $22.86(1)$ & $<0.001$ \\
\hline Unique enzyme in HIV virus & $67(44.66)$ & $124(82.66)$ & $46.81(1)$ & $<0.001$ \\
\hline $1^{\text {st }} \mathrm{Ag}$ to appear in blood & 1 & $11(7.33)$ & $8.68(1)$ & $<0.005$ \\
\hline
\end{tabular}

A Prospective study was conducted at RIMS Medical College, Kadapa, Andhra Pradesh in July and September 2015. 150 students of $4^{\text {th }}$ semester were included after taking their consent. The aim of the study was explained to them beforehand. The importance of answering the questionnaire without consultations/ discussions was stressed. A questionnaire having 30 items of closed ended except three and subjective items were administered for both pre \& post-test evaluation. Questionnaire was prepared in such a way to assess the knowledge of students on current updates, HIV antigens $\&$ enzymes, modes of transmission, symptoms, vulnerable groups, opportunistic infections, testing strategies, treatment and preventive methods. Base line the was assessed by pretest evaluation. Post-test evaluation was done two months after teaching

Statistical Analysis: Chi- square test was used to analyze the obtained data ( 2 X 2 contingency table). 
Table 3: Showing results on Modes of Transmission of HIV/AIDS

\begin{tabular}{|l|l|l|l|l|}
\hline Modes of transmission & $\begin{array}{l}\text { Pre-test Number }(\%) \\
\text { (Total no-135) }\end{array}$ & $\begin{array}{l}\text { Post-test Number } \\
(\%) \\
(\text { Total no-130) }\end{array}$ & $\begin{array}{l}\text { Chi -square } \\
(\mathrm{df})\end{array}$ & $\mathrm{p}$ value \\
\hline Sexual route & $110(73.33)$ & $147(98)$ & $37.16(1)$ & $<0.001$ \\
\hline Blood Transfusion & $105(70)$ & $135(90)$ & $18.75(1)$ & $<0.001$ \\
\hline Vertical transmission & $35(23.33)$ & $43(28.66)$ & $1.10(1)$ & $>0.1$ \\
\hline Contaminated needles \& syringes & $42(28)$ & $67(44.66)$ & $9.00(1)$ & 0.005 \\
\hline All & $5(3.33)$ & $19(12.66)$ & $8.87(1)$ & $<0.005$ \\
\hline
\end{tabular}

Table 4: Showing results on modes by which HIV/AIDS is not transmitted

\begin{tabular}{|l|l|l|l|l|}
\hline $\begin{array}{l}\text { modes by which HIV/AIDS is not } \\
\text { transmitted }\end{array}$ & $\begin{array}{l}\text { Pre-test Number } \\
(\%) \\
(\text { Total no-150) }\end{array}$ & $\begin{array}{l}\text { Post-test Number } \\
(\%) \\
(\text { Total no-150) }\end{array}$ & $\begin{array}{l}\text { Chi -square } \\
(\mathrm{df})\end{array}$ & $\mathrm{p}$ value \\
\hline 1. Touch \& Hand shake & $113(75.33)$ & $126(84)$ & $3.47(1)$ & $>0.05$ \\
\hline 2. Hugging & $7(4.66)$ & $30(20)$ & $16.3(1)$ & $<0.001$ \\
\hline 3.Sharing of rooms, toilets \& clothes & $46(30.66)$ & $91(60.66)$ & $27.20(1)$ & $<0.001$ \\
\hline 4. Playing together & 0 & $2(1.33)$ & & \\
\hline 5. Eating together & $44(29.33)$ & $32(21.33)$ & $2.53(1)$ & $>0.1$ \\
\hline 6. Dry kiss & $11(7.33)$ & $37(24.66)$ & $16.76(1)$ & $<0.001$ \\
\hline 7. Mosquito bite & $12(8)$ & $11(7.33)$ & $0.04(1)$ & $>0.5$ \\
\hline
\end{tabular}

Table 5: Showing results on vulnerable groups of HIV/AIDS

\begin{tabular}{|l|l|l|l|l|}
\hline Name of the vulnerable group & $\begin{array}{l}\text { Pre-test Number }(\%) \\
\text { (Total no-150) }\end{array}$ & $\begin{array}{l}\text { Post-test Number }(\%) \\
(\text { Total no-150) }\end{array}$ & $\begin{array}{l}\text { Chi -square } \\
(\mathrm{df})\end{array}$ & $\mathrm{p}$ value \\
\hline Commercial sex workers & $7(4.66)$ & $15(10)$ & $3.13(1)$ & $>0.05$ \\
\hline Truck drivers & - & $15(10)$ & & \\
\hline Repeated blood transfusions & $2(1.33)$ & $4(2.66)$ & $0.68(1)$ & $>0.5$ \\
\hline Intra venous drug users & - & $5(3.33)$ & & \\
\hline Persons with multiple sex partners & - & $5(3.33)$ & & \\
\hline
\end{tabular}

Table 6: Showing results on symptoms of HIV/AIDS

\begin{tabular}{|l|l|l|l|l|}
\hline Symptoms & $\begin{array}{l}\text { Pre-test Number }(\%) \\
\text { (Total no-150) }\end{array}$ & $\begin{array}{l}\text { Post-test } \\
\text { Number }(\%) \\
\text { (Total no-150) }\end{array}$ & $\begin{array}{l}\text { Chi -square } \\
(\mathrm{df})\end{array}$ & $\mathrm{p}$ value \\
\hline Fever & $13(8.66)$ & $33(22)$ & $10.27(1)$ & $<0.005$ \\
\hline Diarrhea & $2(1.33)$ & $3(2)$ & $0.20(1)$ & $>0.5$ \\
\hline Weight loss & $34(22.66)$ & $44(29.33)$ & $1.73(1)$ & $>0.1$ \\
\hline Generalized lymphadenopathy & - & $14(9.33)$ & & \\
\hline
\end{tabular}

The knowledge of students regarding vulnerable groups, symptoms of HIV/AIDS, testing centers and strategies, treatment \& prevention, indicator diseases of HIV/AIDS and opportunistic infections in HIV/AIDS was high after intervention as shown in Table 5-10.

Table 7: Showing knowledge on HIV \& AIDS Testing 


\begin{tabular}{|l|l|l|l|l|}
\hline Item & $\begin{array}{l}\text { Pre-test Number }(\%) \\
\text { (Total no-150) }\end{array}$ & $\begin{array}{l}\text { Post-post } \\
\text { Number }(\%) \\
\text { Total no-150) }\end{array}$ & $\begin{array}{l}\text { Chi -square } \\
(\mathrm{df})\end{array}$ & p value \\
\hline ICTC stands for & $32(21.33)$ & $46(30.66)$ & $3.39(1)$ & $>0.05$ \\
\hline PPTCT stands for & $25(16.66)$ & $66(44)$ & $26.51(1)$ & $<0.001$ \\
\hline Strategies for HIV testing & $13(8.66)$ & $36(24)$ & $12.9(1)$ & $<0.001$ \\
\hline Number of tests in ICTC & $5(3.33)$ & $32(21.33)$ & $22.47(1)$ & $<0.001$ \\
\hline Number of tests in Blood Bank & $9(6)$ & $18(12)$ & $3.29(1)$ & $>0.05$ \\
\hline DBS stands for & - & $3(2)$ & & \\
\hline
\end{tabular}

Table 8: Showing knowledge on Treatment \& Prevention

\begin{tabular}{|c|c|c|c|c|}
\hline Item & $\begin{array}{l}\text { Pre-test Number } \\
(\%) \\
(\text { Total no-150) }\end{array}$ & $\begin{array}{l}\text { Post-test Number } \\
(\%) \\
(\text { Total no-150) }\end{array}$ & $\begin{array}{l}\text { Chi -square } \\
\text { (df) }\end{array}$ & $\mathrm{p}$ value \\
\hline Zidovudine in PEP & $4(2.66)$ & $86(57.33)$ & $104.5(1)$ & $<0.001$ \\
\hline PEP should be taken within $2 \mathrm{hrs}$ & $2(1.33)$ & $43(28.66)$ & $43.94(1)$ & $<0.001$ \\
\hline PEP should be taken within $72 \mathrm{hrs}$ & $24(16)$ & $75(50)$ & $39.21(1)$ & $<0.001$ \\
\hline $\begin{array}{l}\text { Start treatment when CD4 count } \\
\text { is }<200\end{array}$ & $10(6.66)$ & $51(34)$ & $34.59(1)$ & $<0.001$ \\
\hline HAART means & $18(12)$ & $43(28.66)$ & $12.86(1)$ & $<0.001$ \\
\hline $\begin{array}{l}\text { Is there any drug to prevent vertical } \\
\text { transmission- Yes }\end{array}$ & $97(64.66)$ & $119(79.33)$ & $8(1)$ & $<0.005$ \\
\hline $\begin{array}{l}\text { Name of the drug to prevent vertical } \\
\text { transmission }\end{array}$ & - & $33(22)$ & & \\
\hline $\begin{array}{l}\text { Right choice to prevent HIV during } \\
\text { Sex }\end{array}$ & $109(72.66)$ & $138(92)$ & $19.27(1)$ & $<0.001$ \\
\hline No Permanent cure for HIV infection & $119(79.33)$ & $147(98)$ & $26(1)$ & $<0.001$ \\
\hline No vaccine for HIV/AIDS & $131(87.33)$ & $126(84)$ & $0.67(1)$ & $>0.1$ \\
\hline
\end{tabular}

Table 9: Showing results on Indicator Diseases of HIV/AIDS

\begin{tabular}{|l|l|l|l|l|}
\hline Name of the Disease & $\begin{array}{l}\text { Pre-test } \\
\text { Number }(\%) \\
\text { (Total no-135) }\end{array}$ & $\begin{array}{l}\text { Post-test Number } \\
(\%) \\
(\text { Total no-130) }\end{array}$ & $\begin{array}{l}\text { Chi -square } \\
(\mathrm{df})\end{array}$ & $\mathrm{p}$ value \\
\hline Extensive tuberculosis & $48(32)$ & $92(61.33)$ & $25.92(1)$ & $<0.001$ \\
\hline Esophageal candidiasis & $2(1.33)$ & $33(22)$ & $31.08(1)$ & $<0.001$ \\
\hline Kaposi's sarcoma & $5(3.33)$ & $20(13.33)$ & $9.81(1)$ & $<0.005$ \\
\hline $\begin{array}{l}\text { Others like toxoplasmosis, Generalized } \\
\text { Strongyloidosis, PCP, Cryptococcus } \\
\text { meningitis, lymphomas, CMV retinitis etc }\end{array}$ & $2(1.33)$ & $21(14)$ & $16.99(1)$ & $<0.001$ \\
\hline
\end{tabular}

Table 10: Showing results on opportunistic Diseases in HIV/AIDS

\begin{tabular}{|l|l|l|l|l|}
\hline Name of the Disease & $\begin{array}{l}\text { Pre-test Number } \\
(\%) \\
(\text { Total no-150) }\end{array}$ & $\begin{array}{l}\text { Post-test } \\
\text { Number }(\%) \\
(\text { Total no-150) }\end{array}$ & $\begin{array}{l}\text { Chi -square } \\
(\mathrm{df})\end{array}$ & $\mathrm{p}$ value \\
\hline Candidiasis & 3 & $44(29.33)$ & 70.12 & $<0.001$ \\
\hline Tuberculosis & 14 & $78(52)$ & 64.21 & $<0.001$ \\
\hline Cryptococcal meningitis & 0 & $20(13.33)$ & & $<0.001$ \\
\hline Toxoplasmosis & 2 & $22(14.66)$ & 18.11 & $<0.001$ \\
\hline $\begin{array}{l}\text { Others (PCP, diarrhea due to Isospora, } \\
\text { C.parvum, CMV retinitis, Histoplasmosis, } \\
\text { etc) }\end{array}$ & 2 & $18(12)$ & 13.71 & \\
\hline
\end{tabular}




\section{Discussion}

Health education, particularly Information, Education and Communication (IEC) and Behaviour change Communication (BCC) are the key strategies for controlling HIV/AIDS epidemic [6]. Several studies were in agreement with the fact that health education intervention definitely has a positive effect on awareness levels regarding HIV/AIDS [4,7,8]. Properly integrating HIV training into the medical school curriculum improves knowledge of medical students [9]. An integrated course curriculum involving principles of both primary and palliative care principles will improve the efficiency of the undergraduate medical education programme [10]. By involving all the teaching departments in meeting the objectives defined for the overall course in HIV medicine for undergraduate medical students, the course can be smoothly incorporated into the curriculum with no apparent extra burden on the student [5].

The knowledge of students after teaching curriculum regarding HIV/AIDS was high in all aspects when compared to pre intervention. Awareness and knowledge of students was improved very much in post intervention session regarding several facts about HIV/AIDS. But they were unaware that $\mathrm{P}^{24}$ antigen is the $1^{\text {st }}$ antigen to appear in blood and it is an important marker in early diagnosis of HIV/AIDS. Awareness on vertical transmission was also poor, which is important in preventing transmission to newborns. They should acquire knowledge about the modes by which HIV/AIDS is not transmitted. Being future medical practitioners they should have complete knowledge about transmission and non-transmission routes to alleviate misconceptions in society.

Prevention is better than cure. If health care providers know who are vulnerable to HIV/AIDS, they could concentrate on these groups for implementation of preventive measures. Unless clinicians know when to suspect HIV/AIDS, they cannot diagnose the infection. Especially in case of HIV/AIDS high suspicion is needed for early diagnosis. Being future clinicians, medical students should be trained in these aspects. Around 50\% knew about PEP and only 22\% were aware that nevirapine prevents vertical transmission. It is must to understand the signs and symptoms of opportunistic infections (OI) which commonly strike HIV sero positive individuals. By that early detection and treatment of OI will improve the quality of life of
HIV sero positive individuals. Students' knowledge about indicator diseases and opportunistic infections was still lagging behind in post intervention session. Their knowledge in the above aspects requires further intervention.

A study by Sandheep sugandh etal revealed that $94.8 \%$ of students were having knowledge that there is no complete cure for AIDS before the intervention. After health education, all the students in their study gained the knowledge about this. In the same study, $92.4 \%$ of students knew that AIDS is preventable and $93.6 \%$ gained this knowledge in post-intervention assessment. In their study, $76.8 \%$ were having knowledge about non-availability of effective vaccine for AIDS and after the health education session, $91.2 \%$ got the knowledge [4].

In the present study $79.33 \% \& 98 \%$ knew that there was no permanent cure, $87.33 \%$ \& $84 \%$ were aware that there was no vaccine and $72.66 \%$ \& $92 \%$ were have knowledge that HIV/AIDS can be prevented by barrier contraceptives like condoms. It was surprising that in post-intervention assessment less number of students answered the non-availability of vaccine for HIV/AIDS than pre intervention assessment. Probably they were mistaken the trails of HIV vaccine for its availability. Whatever maybe the reason they should be educated in the fact that vaccine is not available for HIV/AIDS at present and should be reassessed. Particularly in the case of a newer subject of learning such as HIV/AIDS, assessments can guide the teachers as well as the students about parts of the course that have been successful and parts which need to be improved [5].

Pre and post test evaluation in medical students on HIV/AIDS was done in few studies and they are not of open ended. So it is difficult to compare with those studies. Post test evaluation was done after an interval of two months of curriculum intervention, so that answers should be recollected from their memory. Probably this was the reason for not getting still better results even though the obtained results were satisfied.

There is a strong need for imparting HIV related education right from the very beginning of medical curriculum so as to demystify misconceptions among medical students $[6,11]$. The school education system all over the world play a major role in shaping the attitudes, opinions and the behavior of young people [12]. Curriculum on HIV/AIDS played an important role on the awareness and knowledge of students on 
HIV/AIDS [13]. Some other studies also opined that intervention definitely improved the knowledge of individual on HIV/AIDS in several aspects $[14,15]$.

WHO strongly recommends the incorporation of knowledge of HIV/AIDS in medical syllabus starting from the $1^{\text {st }}$ year. First is the understanding of and skills in the management of a chronic HIV disease with a gamut of associated opportunistic infections; second is the need to overcome prejudicial attitudes that can impede high quality care, and third is the development of skills in coping with the psychological demands of certain types of care of patients. Experience shows that while dealing with subjects like STI, HIV and AIDS, their teaching should be integrated and carried out jointly by teachers from many disciplines, e.g. medicine, preventive medicine, and social and behavioural sciences. Moreover, many institutions have found that innovative teaching-learning methods are better at influencing attitudes [5]. At present the medicos are concentrating on their regular curriculum. But apart from that they require knowledge on current affairs, infectious diseases that are prevalent at present, their transmission, prevention and treatment. This will be obtained when regular seminars, group discussions, quiz programmes and CMEs -conducting regularly throughout the medical course in addition to their curriculum. Medical teaching institutions are continuously producing hundreds of health care providers every year. So it is must to conduct awareness programmes and should take feedback from students attended to know the efficacy of such programs which can improve their attitudes towards infectious diseases.

\section{Conclusions}

1. Awareness of students on HIV/AIDS was improved in post-intervention assessment.

2. Few students (11/150) only knew about p 24 antigen.

3. Students' knowledge about modes and non-modes of transmission of HIV still needs intervention.

4. Their concept on vertical transmission and its prevention has to be improved.

5. Regarding vulnerable groups, symptoms, testing strategies - their awareness was poor.

Recommendations: Being future clinicians, medical students should have complete knowledge on HIV/AIDS especially on HIV binding sites, modes and non-modes of transmission, vulnerable groups, symptoms, testing strategies, treatment and prevention methods. To obtain this knowledge medical students should have teaching classes starting from their first year of curriculum. Clinical orientation should be imparted by posting them to PPTCT, ICTC \& ART centers in small groups and encourage them to interact directly with HIV seropositive individuals. CMEs on HIV/AIDS should be conducted exclusively for medicos with their active participation. Their knowledge should be assessed at regular intervals by conducting tests.

\section{Funding: Nil,Conflict of interest: None. Permission of IRB: Yes}

\section{References}

1. Chiamaka N. Umeh, E. James Essien, Emmanuel N. Ezedinachi, and Michael W. Ross, "Knowledge, Beliefs and Attitudes about HIV/AIDS related issues, and the Sources of Knowledge among Health Care Professionals in Southern Nigeria." J R Soc Promot Health. 2008 Sep; 128(5): 233-239. (HHS public access available in PMC 2008 oct 7; PMCID: PMC 2562902; NIHMSID: NIHMS 7286)

2. Farah D Shaikh, Shahzad A. Khan, Michael W. Ross and Richard M. Grimes "Knowledge and attitudes of Pakistani medical students towards HIV-positive and/or AIDS patients" Psychology, Health \& Medicine, January 2007; 12(1): 7 - 17

3. NACO Annual Report 2013-14 (30-6-14): India's voice against AIDS, Dept. of AIDS control, Ministry of H\&FW, GOI.

4. SandheepSugathan and Mohammed Swaysi. Knowledge about HIV/AIDS among Premedical Students in Misurata, Libya and the Effectiveness of a Health Education Intervention. Community Medicine \& Health Education, 2012; 2 (10 http://dx.doi.org/10.4172/2161-0711.1000187

5. Teaching HIV/AIDS in Medical Schools by WHO Regional Office for South-East Asia, New Delhi 1999; page $1-49$

6. Abhimanyu Singh Chauhan, Dr.Mohammad Akhtar Hussain, Dr. SangamitraPati, Srinivas Nallala, Jayanti Mishra. Knowledge and attitudes related to HIV/AIDS among medical and allied health sciences students. Indian Journal of Communiy Health 2011; 23 (2):96-98 
7. Shankar PR, Subish P, Paudel R, Alam K. Perception And Knowledge About HIV/AIDS Among Students in a Medical College in Western Nepal. Saarc J.Tuber. Lung Dis.HIV/AIDS, 2009; VI (2): pp 11-16

8. Dr. Harshad Patel, Dr. Ashish Nayak, Dr. Naresh Chauhan, Dr. DharmendraJankar, Dr. DevangRaval, Dr. M.P.Singh. "Evaluation Of Pre Test And Post Test Knowledge After Intensive ICTC Team Training Among Health Care Workers In Bhavnagar District" NJIRM 2013; 4(6) : 84-87

9.Michael Platten, Ha N Pham and Huy V Nguyen, "Knowledge of HIV and factors associated with attitudes towards HIV among final-year medical students at Hanoi medical university in Vietnam" BMC Public Health 2014, 14:265 doi:10.1186/1471-2458-14265

10.Sameer Valsangkar, Trupti N Bodhare, Shripad B Pande,1 Samir D Bele, and B Sitarama Rao, "Evaluation of Knowledge Among Interns in a Medical College Regarding Palliative Care in People Living with HIV/AIDS and the Impact of a Structured Intervention", Indian J Palliat Care. 2011 Jan-Apr; 17(1): 6-10

11. Sanjay Kini, Sneha D Mallya, Veena G Kamath,
Asha Kamath, AmbikaCoondoo, KarthikVasudevanIyer, Sujayendra D Murali "Knowledge and Attitude about HIV/AIDS among medical students in a private medical college in costal Karnataka" Global Journal of Medicine and Public Health, 2014; 3(2):1-5

12. Dr.Shikha Trivedi. HIV/AIDS Awareness level in Secondary Schools of India after twenty seven years. IOSR Journal of Humanities and Social Science, March 2014;19(3):ver2:pp 71-75

13. Bharathi.M, Radha.M “ Awareness and Knowledge of Adolescent girl Students from a Government High school for girls on HIV/AIDS" J Pharm Biomed Sci 2015; 05 (05): 408-414

14. L. Cherian, LS Maphoso, "Measurement of the effectiveness of HIV/AIDS intervention programme on knowledge, attitudes and behavior of the South African Polise service employees" , Curationis, Dec 2009; 32(4):4-18.

15. Angella Musiimenta, "A controlled pre - post evaluation of a computer based HIV/AIDS education on students' sexual behavior, knowledge and attitudes" Online journal of public health informatics, 2012; 4(1): ojphi- vil.4017.

\section{How to cite this article?}

Bharathi M, B Naga Srilatha, M Sasidhar, A Sasikala. Evaluation of knowledge \& awareness of medical students on HIV/AIDS before and after teaching curriculum. Int $J$ Med Res Rev 2015;3(9):1042-1048. doi: 10.17511/ijmrr.2015.i9.191. 